\title{
FOREWORD BRUCE SPRINGSTEEN
}

I had completed most of the "Tom Joad" record when one night, unable to sleep, I pulled this book down off my living room shelf. I read it in one sitting and I lay awake that night disturbed by its power and frightened by its implications. In the next week, I wrote "Youngstown" and "The New Timer." Dale Maharidge and Michael Williamson put real lives, names, and faces on statistics we'd all been hearing about throughout the Eighties. People who all their lives had played by the rules, done the right thing, and had come up empty, men and women whose work and sacrifice had built this country, who'd given their sons to its wars and then whose lives were marginalized or discarded. I lay awake that night thinking: What if the craft I'd learned was suddenly deemed obsolete, no longer needed? What would I do to take care of my family? What wouldn't I do?

Without getting on a soapbox, these are the questions Dale Maharidge and Michael Williamson pose with their words and pictures. Men and women struggling to take care of their own in the most impossible conditions and still moving on, surviving.

As we tuck our children into bed at night, this is an America many of us fail to see, but it is a part of the country we live in, an increasing part. I believe a place and a people are judged not just by their accomplishments, but also by their compassion and sense of justice. In the future, that's the frontier where we will all be tested. How well we do will be the America we leave behind for our children and grandchildren. 
This was the introduction I wrote in 1995 for Journey to Nowhere, Dale and Michael's book telling the story of the losses suffered by American labor in the second half of the twentieth century. Someplace Like America takes the measure of the tidal wave thirty years and more in coming, a wave that Journey first saw rolling, dark and angry, on the horizon line. It is the story of the deconstruction of the American dream, piece by piece, literally steel beam by steel beam, broken up and shipped out south, east, and to points unknown, told in the voices of those who've lived it. Here is the cost in blood, treasure, and spirit that the post-industrialization of the United States has levied on its most loyal and forgotten citizens, the men and women who built the buildings we live in, laid the highways we drive on, made things, and asked for nothing in return but a good day's work and a decent living.

It tells of the political failure of our representatives to stem this tide (when not outright abetting it), of their failure to steer our economy in a direction that might serve the majority of hard-working American citizens, and of their allowing an entire social system to be hijacked into the service of the elite. The stories in this book let you feel the pounding destruction of purpose, identity, and meaning in American life, sucked out by a plutocracy determined to eke out its last drops of tribute, no matter what the human cost. And yet it is not a story of defeat. It also details the family ties, inner strength, faith, and too-tough-to-die resilience that carry our people forward when all is aligned against them.

When you read about workers today, they are discussed mainly in terms of statistics (the unemployed), trade (the need to eliminate and offshore their jobs in the name of increased profit), and unions (usually depicted as a purely negative drag on the economy). In reality, the lives of American workers, as well as those of the unemployed and the homeless, make up a critically important cornerstone of our country's story, past and present, and in that story, there is great honor. Dale and Michael have made the telling of that story their life's work. They present these men, women, and children in their full humanity. They give voice to their humor, frustration, rage, perseverance, and love. They invite us into these stories to understand the hard times and the commonality of experience that can still be found just beneath the surface of the modern news environment. In giving us back that feeling of universal connectedness, they create room for some optimism that we may still find our way back to higher ground as a country and as a people. As the folks whose voices sing off these pages will tell you, it's the only way forward. 